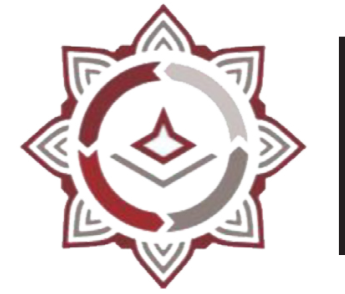

BISNIS: Jurnal Bisnis dan Manajemen Islam

P-ISSN: 2442-3718, E-ISSN: 2477-5533

Volume 9, Nomor 2, Desember 2021 (PP : 301-318)

https://journal.iainkudus.ac.id/index.php/Bisnis/index

http://dx.doi.org/10.21043/bisnis.v9i2.11832

\title{
PENGARUH LOCUS OF CONTROL, KEPEMIMPINAN TRANSFORMASIONAL DAN SPIRITUAL KERJA TERHADAP KINERJA KARYAWAN
}

\author{
Akhmad Darmawan', Fatmah Bagis ${ }^{2}$, Intan Anggun Puspita Anggraini ${ }^{3}$ \\ Universitas Muhammadiyah Purwokerto ${ }^{1}$, Universitas Muhammadiyah Purwokerto², \\ Universitas Muhammadiyah Purwokerto ${ }^{3}$ \\ Akhmaddarmawan@ump.ac.id,fatmahbagis2014@gmail.com, intananggun901@gmail.com
}

\begin{abstract}
This research aims to find out the influence of locus of control, transformational leadership and spiritual work on employee performance (Case Study on Employees Perum Perhutani KPH Banyumas Timur). The population in the study was an employee of the production section of Perum Perhutani KPH Banyumas Timur and a sample used by 145 people. The method used in this study is a case study of employees of the production section of Perum Perhutani KPH Banyumas Timur. Questionnaires were distributed to 145 employees of the production section as respondents. Data analysis techniques use multiple linear regression analysis. The results showed that Locus Of Control, Transformational and Spiritual Leadership of work had a simultaneous effect on the performance of perum perhutani KPH Banyumas Timur, Locus Of Control significantly on the performance of perum perhutani KPH Banyumas Timur, transformational leadership had a significant effect on the performance of perum perhutani KPH Banyumas Timur, spiritual.
\end{abstract}

Keywords: Locus of Control, Transformational and Spiritual Work, Employee Performance

\begin{abstract}
Abstrak
Penelitian ini bertujuan untuk mengetahui pengaruh locus of control, kepemimpinan transformasional dan spiritual kerja terhadap kinerja karyawan (studi Kasus Pada Karyawan Perum Perhutani KPH Banyumas Timur). Populasi dalam penelitian ini adalah karyawan bagian produksi Perum Perhutani KPH Banyumas Timur dan sampel yang digunakan 145 orang. Metode yang digunakan dalam penelitian ini adalah studi kasus karyawan
\end{abstract}


bagian produksi Perum Perhutani KPH Banyumas Timur. Kuesioner disebarkan kepada 145 karyawan bagian produksi sebagai responden. Teknik analisis data menggunakan analisis regresi linier berganda. Hasil penelitian menunjukan bahwa Locus of Control, Kepemimpinan transformasional dan spiritual kerja berpengaruh secara simultan terhadap kinerja perum perhutani KPH Banyumas Timur, Locus of Control berpengaruh signifikan terhadap kinerja perum perhutani KPH Banyumas Timur, kepemimpinan transformasional berpengaruh signifikan terhadap kinerja perum perhutani KPH Banyumas Timur, spiritual kerja berpengaruh signifikan terhadap kinerja perum perhutani KPH Banyumas Timur.

Kata Kunci: Locus of Control, Kepemimpinan Transformasional dan Spiritual Kerja, Kinerja Karyawan

\section{PENDAHULUAN}

Sumber Daya Manusia (SDM) merupakan salah satu sumber daya utama yang berperan menjadi motor penggerak, dalam melakukan aktivitas untuk mencapai tujuannya. Baik sebagai perusahaan berorientasi laba maupun sebagai ragam kinerja tergantung kepada kinerja seluruh anggota oraganisasi itu sendiri. Unsur individu manusialah yang memegang peranan penting dan sangat menentukan keberhasilan organisasi tersebut.

Banyumas merupakan kota devisi regional jawa tengah dari beberapa industri yang terdapat di kabupaten Banyumas Provinsi Jawa Tengah Indonesia. Salah satunya keberadaan industri perhutani di perusahaan Perum Perhutani KPH Banyumas Timur yang memproduksi non kayu dan kayu. Produk non kayu semisalnya getahpohon pinus yang dijadikan gondorikan rifat, selain itu produk yang berupa dijadikan triplek. Yang berdiri pada tahun 1978, Perum Perhutani Kesatuan Pemangkuan Hutan (KPH) Banyumas Timur adalah merupakan satuan unit kerja di wilayah Perum Perhutani Divisi Regional Jawa Tengah. Luas wilayahnya 46.453,00 Ha meliputi kawasan hutan yang berada di 4 Kabupaten, yaitu Kabupaten Cilacap 1.872,71 ha (4,03\%), Kabupaten Banyumas 17.897,10 ha (38,53\%), Kabupaten Purbalingga 15.079,91 ha (32,46\%) dan Kabupaten Banjarnegara 11.603,28 ha (24,98\%). Hal ini didukungnya sumber daya manusia dalam peningkatan kualitas petugas pengamanan hutan, patroli rutin gabungan dan adanya program komunikasi sodial atau program PHBM (Pengelolaan hutan bersama masyarakat). (https://perhutani.co.id)

Kinerja merupakan perilaku nyata yang di hasilkan setiap orang sebagai prestasi kerja yang di hasilkan oleh karyawan sesuai dengan perannya dalam sebuah organisasi, dimana untuk mendapatkan kinerja yang baik dari karyawan. Kinerja 
adalah kuantitas, kualitas dan waktu yang digunakan dalam menjalankan tugas. Kuantitas adalah hasil yang dapat dihitung sejauh mana seseorang dapat berhasil mencapai tujuan yang telah ditetapkan (Dessy, 2016).

Penelitian mengenai faktor kinerja karyawan pada industri telah dilakukan beberapa penelitian menurut Puspitayanti, (2015), Dessy dkk (2016), Menyebutkan bahwa terdapat pengaruh signifikan antara locus of control dan kepemimpinan tranfosmasional terhadap kinerja karyawan. Sedangkan terdapat beberapa penelitian sebelumnya pada penelitian Annida (2018), menyebutkan bahwa terdapat pengaruh signifikan antara locus of control terhadap kinerja karyawan.

Locus of control dapat difenisikan yang mencerminkan sifat seseorang untuk lebih percaya akan kontrol dalam diri pribadinya dalam kehidupannya daripada dikendalikan oleh kekuatan dari luar pribadinya, bahwa locus of control baik internal maupun eksternal merupakan tingkatan seorang individu berharap bahwa hasil dari perilaku mereka tergantung pada perilaku mereka sendiri atau karakteristik personal mereka. Hal ini merupakan salah satu cara agar karyawan tidak mengalami gangguan dalam menyelesaikan pekerjaannya, karena setiap individu merasa dapat mengontrol dirinya sendiri maka mereka akan lebih mampu mengendalikan akibat dan yang terjadi dalam lingkungan sehingga akan lebih merasa puas dengan pencapaian yang dilakukan, karena locus of control mempengaruhi kinerja karyawan. Sedangkan terdapat beberapa penelitian sebelumnya menurut Puspitayanti, (2015) Sari, (2018) Narendra, (2018) menyebutkan bahwa terdapat pengaruh signifikan antara Locus of control terhadap kinerja karyawan.

Namun, hal ini berbeda dengan peneletian dari Haryanto, (2020) yang mengatakan bahwa locus of control tidak berpengaruh signifikan terhadap kinerja karyawan.

Kepemimpinan transformasional adalah perspektif kepemimpinan yang menjelaskan bagaimana pemimpin mengubah tim atau organisasi dengan menciptakan, mengomunikasikandanmembuatmodelvisiuntukorganisasiatauunitkerjadanmemberi inspirasi pekerja untuk berusaha mencapai visi tersebut (Kharis, 2015). Kepemimpinan Transformasional memiliki pengaruh yang paling kuat untuk mempengaruhi kinerja karyawan. Sedangkan terdapat beberapa penelitian sebelumnya pada penelitian Puspitayanti (2015), Yuwono dkk (2020) menyebutkan bahwa berpengaruh signifikan antara kepemimpinan transformasional terhadap kinerja karyawan. Namun, hal ini berbeda dengan penelitian dari Gita (2016) yang menyatakan bahwa kepemimpinan transformasional tidak berpengaruh terhadap kinerja karyawan. 
Nasrul (2018) menyatakan bahwa spiritualitas di tempat kerja merupakan sebuah fenomena untuk mencari kehidupan yang bermakna dan mendapatkan pengetahuan yang lebih dalam, dimana karyawan merasa termotivasi untuk menemukan makna dan tujuan keberadaan mereka. Menurut pendapat lain spiritual dapat diartikan perasaan yang memberikan koneksi antara diri sendiri dan orang lain (Sudarman, 2017). Spiritual sangat penting di tingkat pribadi dan organisasi dan mengesankan hati nurani orang, hal itu akan menciptakan rasa tanggung jawab terhadap tanggung jawab kehidupan sehari - har. Hal ini di dukung oleh penelitian yang dilakukan oleh Sudarman (2017) menyatakan bahwa spiritual berpengaruh positif dan signifikan terhadap kinerja karyawan berikutnya pada penelitian Hanah (2019) menyebutkan bahwa terdapat pengaruh signifikan antara Spiritual kerja terhadap kinerja karyawan, hasil berbeda diperoleh dari penelitian Octavia (2020) menyatakan bahwa spritualitas kerja tidak berpengaruh signifikan terhadap kinerja karyawan.

Berdasarkan uraian tersebut di atas, penulis tertarik untuk meneliti pengaruh dari locus of control, kepemimpinan tranformasional, dan spiritual at work terhadap kinerja karyawan. Penelitian ini merupakan pengembangan dari penelitian terdahulu yang dilakukan Galan dan Edy, (2018). Karena pada Perum Perhutani KPH Banyumas Tinur terdapat fenomena yang mengarah ke locus of control sehingga peneliti tertarik melakukan sebuah penelitian. Hal ini sejalan dengan penelitian sebelumnya menurut Puspitayanti, (2015) bahwa pengaruh locus of control terhadap kinerja karyawan hasilnya signifikan.

Dalam hal ini peneliti berharap bahwa penelitian yang dilakukan di Perum Perhutani KPH Banyumas Timur dapat bermanfaat bagi perusahaan serta mengetahui tingkat kinerja karyawan yang terdapat di Perum Perhutani KPH Banyumas Timur. Berdasarkan identifikasi masalah diatas menyatakan bahwa terdapat fenomena mengarah ke locus of control,mengatakan bahwa karyawan tidak mengalami gangguan dalam menyelesaikan pekerjaannya, karena setiap individu merasa dapat mengontrol dirinya sendiri maka mereka akan lebih mampu mengendalikan akibat dan yang terjadi dalam lingkungan sehingga akan lebih merasa puasa dengan pencapaian yang dilakukan, maka peneliti tertarik untuk mengkaji lebih dalam untuk dijadikan penelitian dengan judul "Pengaruh Locus of Control, Kepemimpinan Transformasional dan Spiritual Kerja Terhadap Kinerja Karyawan Pada Karyawan Perum Perhutani KPH Banyumas Timur“. 


\section{KAJIAN LITERATUR}

\section{Kinerja Karyawan}

Mathis dan Jackson (2002) mengemukakan bahwa kinerja pada dasarnya adalah apa yang dilakukan atau tidak dilakukan karyawan. Kinerja karyawan adalah yang mempengaruhi seberapa banyak mereka memberikan kontribusi kepada organisasi yang antara lain meliputi: a. Kualitas output, b. Kuantitas output, c. Jangka waktu output dan d. Kehadiran ditempat kerja. e. Sikap Kooperatif. Kinerja berkaitan erat dengan tujuan, sebagai suatu hasil perilaku kerja seseorang (Davis, 1985; Wayan, 2000). Perilaku kinerja dapat ditelusuri hingga ke faktor-faktor spesifik seperti kemampuan, upaya dan kesulitan tugas (Timpe, 1988). Kinerja sebagai hasil pola tindakan yang dilakukan untuk mencapai tujuan sesuai dengan standar prestasi, kualitatif maupun kuantitatif, yang telah ditetapkan. Kinerja adalah perilaku nyata yang ditampilkan oleh setiap orang sebagai prestasi kerja yang dihasilkan oleh karyawan oleh peran dan institusi mereka. Kinerja pegawai adalah hasil kerja secara kualitas dan kuantitas dicapai oleh seorang pegawai dalam melaksanakan tugasnya sesuai dengan tanggung jawab yang diberikan kepadanya (Bagis, 2021).

\section{Locus Of Control}

Menurut Rotter (1966) menjelaskan bahwa locus of control adalah tingkat sejauh mana seseorang mengharapkan bahwa penguatan atau hasil dari perilaku mereka tergantung pada penilaian mereka sendiri atau karekteristik pribadi (dalam Allen, 2003: 293). Gibson, Ivancevich \& Donnelly (1995: 161) mengatakan bahwa locus of control merupakan karakteristik kepribadian yang menguraikan orang yang menganggap bahwa kendali kehidupan mereka datang dari dalam diri mereka sendiri sebagai internalizers. Orang yang yakin bahwa kehidupan mereka dikendalikan oleh faktor eksternal disebut: ezternalizer. Levenson (1981) menyatakan locus of control adalah keyakinan individu, mengenai sumber penyebab dari peristiwaperistiwa yang dialami dalam hidupnya. Seseorang juga dapat memiliki keyakinan bahwa ia mampu mengatur kehidupannya, bisa juga ia berkeyakinan faktor nasib, keberuntungan, atau kesempatan yang mempunyai pengaruh besar dalam kehidupannya (dalam Robinson, dkk, 1991: 425).

\section{Kepemimpinan Transformasional}

Kepemimpinan adalah kemampuan yang dimiliki seseorang untuk mempengaruhi orang lain untuk bekerja menuju tujuan mereka (Bagis, et al, 2020). 
Gaya kepemimpinan pada dasarnya memiliki pengertian sebagai suatu perwujudan tingkah laku dari pemimpin menyangkut kemampuannya dalam memimpin. Perwujudan tersebut bisa membentuk suatu pola atau bentuk tertentu (Sudaryono, 2014). Flippo dalam Sudaryono (2014) berpendapat gaya kepemimpinan dapat dirumuskan sebagai suatu pola perilaku yang dirancang untuk memadukan kepentingan-kepentingan organisasi dan personalia guna mengejar beberapa sarasaran. Sedangkan Robins dan Judge (2007) mengidentifikasi empat jenis gaya kepemimpinan antara lain : Gaya kepemimpinan kharismatik, Gaya kepemimpinan transaksional, Gaya kepemimpinan transformasional, Gaya kepemimpinan visioner. Maka dapat disimpulkan bahwa gaya kepemimpinan merupakan perilaku yang ditunjukan oleh pemimpin kepada bawahannya dengan tujuan untuk mempengaruhi dan memotivasi bawahannya supaya dapat diarahkan guna mencapai tujuan.

Jexdan Britt (2008) memaparkan bahwa gaya kepemimpinan transformasional (atau biasa disebut juga charismatic leadership) merupakan gaya kepemimpinan yang menggambarkan pemimpin yang tidak hanya mempengaruhi bawahannya namun juga turut menginspirasi mereka untuk bekerja diatas kemampuan mereka. Gaya kepemimpinan transformasional dibentuk dari beberapa atribut, yaitu: 1) Membagi Visi (Providing Vision) 2) Menerapkan Visi (Vision Implementation) 3) Gaya Komunikasi yang Karismatik (Charismatic Communication Style)

\section{Spiritual Kerja}

Zohar dan Marshall (2000) mengartikan kecerdasan spiritual sebagai kecerdasan untuk menghadapi persoalan makna atau value, yaitu kecerdasan untuk menempatkan perilaku dan hidup kita dalam konteks makna yang lebih luas dan kaya, kecerdasan untuk menilai bahwa tindakan atau jalan hidup seseorang lebih bermakna dibandingkan yang lain. Seseorang yang memiliki Kecerdasan Spiritual yang tinggi cenderung menjadi seorang pemimpin yang penuh pengabdian, bertanggung jawab untuk membawakan visi dan nilai yang lebih tinggi dan bisa memberi inspirasi kepada orang lain. Kecerdasan Spiritual dapat digunakan untuk menjadikan manusia lebih cerdas secara spiritual dan agama (Zohar dan Marshall, 2000).

Tanda-tanda kecerdasan spiritual yang telah berkembang dengan baik mencakup hal-hal berikut (Zohar dan Marshall, 2000): a. Kemampuan bersikap fleksibel (adaptif secara spontan dan aktif). b. Tingkat kesadaran diri yang tinggi. c. Kemampuan untuk menghadapi dan memanfaatkan penderitaan. d. Kemampuan 
untuk menghadapi dan melampaui rasa sakit. e. Kualitas hidup yang diilhami oleh visi dan nilai-nilai. f. Keengganan untuk menyebabkan kerugian yang tidak perlu.

\section{Kerangka Pemikiran}

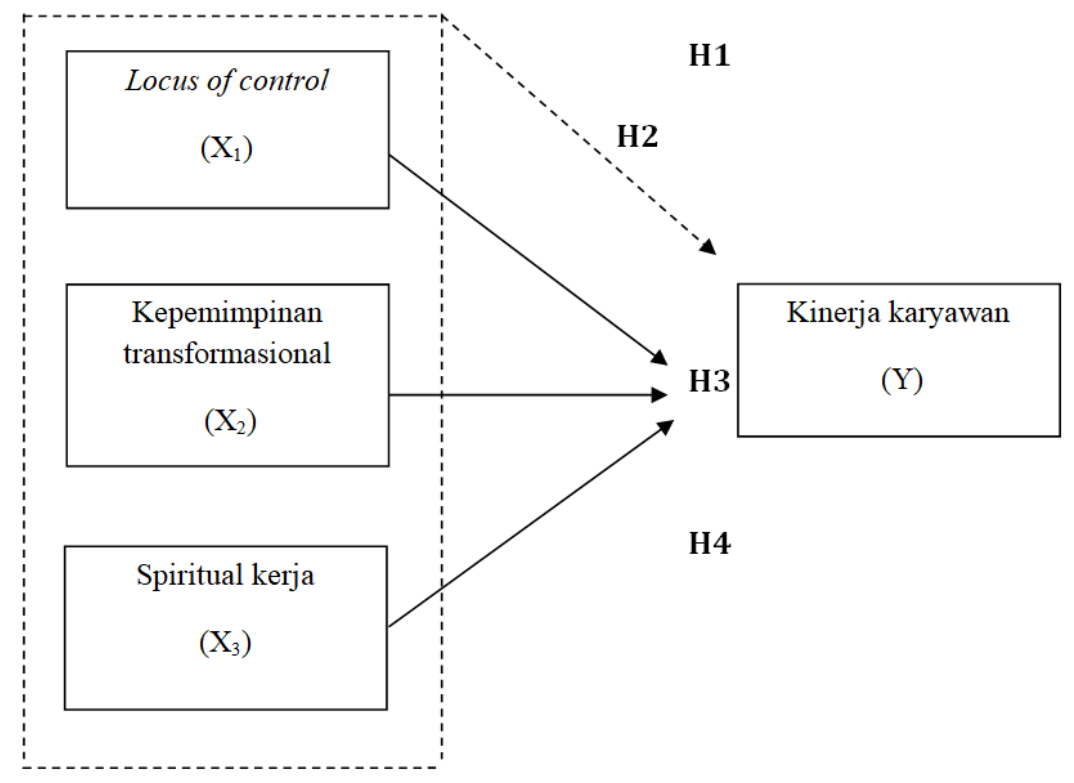

Gambar 1. Kerangka Pemikiran

\section{METODE PENELITIAN}

Penelitian ini merupakan penelitian kuantitatif dan menggunakan metode survey dengan menyebarkan kuesioner kepada responden. Populasi dalam penelitian ini adalah 203 karyawan Perum KPH Banyumas Timur dan sampel yang digunakan sebagai responden sejumlah 145 karyawan. Teknik pengumpulan sampel menggunakan purposive sampling dengan kriteria karyawan tetap dan telah bekerja minimal 1 tahun dan bukan merupakan level pimpinan.

\section{PEMBAHASAN}

Penelitian ini telah melalui pengujian instrument item pernyataan untuk setiap variabel baik dependen maupun independen lolos uji instrumen data dengan hasil pengujian semua instrumen pernyataan di setiap variabel dinyatakan valid dan indikator-indikator yang digunakan dalam pernyataan kuesioner di setiap variabel dinyatakan reliabel. Pada uji asumsi klasik telah diketahui bahwa data 
unstandardized residual telah terdistribusi normal, tidak ada multikolinieritas antar variabel independen dalam model regresi, serta tidak terjadi heteroskedastisitas antar variabel dalam model regresi. Sedangkan untuk uji analisis regresi linier berganda, uji koefisien determinasi (R2), uji F (F test), dan pengujian hipotesis.

Alat analisis yang digunakan adalah uji regresi liner berganda untuk mengetahui pengaruh secara simultan serta pengaruh secara parsial antara variabel dependen dan variabel independen.

\section{Hasil Uji Validitas dan Reliabilitas}

Hasil nilai uji validitas untuk semua indikator lebih dari 0,50 sehingga dapat disimpulkan model tersebut valid, karena telah memenuhi syarat validitas konvergen. Tabel di atas juga menunjukkan nilai composite reliability pada semua variabel lebih dari 0,70. Sehingga dapat disimpulkan bahwa semua variabel yang diteliti telah memenuhi kriteria.

Variabel dalam penelitian ini memiliki nilai Cronbach Alpha > 0,70 (Ghozali, 2018), sehingga semua indikator variabel dalam penelitian ini dinyatakan reliabel atau konsisten.

\section{Hasil Analisis Statistik Desktriptif}

Berdasarkan hasil analisis deskriptif untuk variabel Kinerja Karyawan memiliki variabel tertinggi dengan nilai 4,2897 pada item penyataan efektifitas kuantitas kerja dan penggunaan sumber daya yang artinya karyawan merasa selalu efektif dalam menaikan hasil dari setiap unit penggunaan sumber daya dan berusaha mencapai hasil lebih baik dimasa depan.

Hasil analisis deskriptif locus of control nilai standar deviasi menunjukkan bahwa item pernyataan variabel locus of control sifatnya relatif homogen atau sama. Untuk item pertanyaan tertinggi dengan nilai 4,3724 variabel locus of control berada pada item pernyataan nomor 16, artinya karyawan merasa keberhasilan dan kegagalan merupakan suatu keberuntungan.

Hasil analisis deskriptif variabel kepemimpinan transformasional memiliki nilai standar deviasi menunjukkan bahwa item pernyataan variabel kepemimpinan transformasional sifatnya relatif homogen atau sama. Untuk item pertanyaan tertinggi variabel kepemimpinan transformasional berada pada item pernyataan nomer 4 sehingga karyawan merasa pemimpin selalu dapat memberikan informasi 
yang akurat kepada setiap karyawan. Perolehan informasi dari pimpinan dengan nilai 4,2897.

Sedangkan hasil analisis deskriptif variabel spiritual kerja memiliki nilai mean atau rata-rata sebesar 4 dari 5 skala dalam skala likert yang artinya item pernyataan variabel spiritual kerja dalam posisi setuju, sehingga dapat dinyatakan sudah baik. Item pertanyaan tertinggi dengan nilai 4,2828 variabel spritualitas kerja berada pada item pertanyaan nomer 14 , artinya karyawan merasa pemimpin mengetahui setiap pekerjaan yang dilakukan oleh setiap karyawan.

\section{Analisis Regresi Linier Berganda}

Analisis regresi digunakan untuk menghitung besarnya pengaruh antara variabel bebas yaitu budaya organisasi (X1), komitmen organisasi (X2), dan kepuasan kerja (X3) terhadap variabel terikat yaitu kinerja karyawan (Y). Dengan menggunakan SPSS for windows version 20 didapat model regresi seperti pada Tabel 2 berikut ini:

Tabel 2. Hasil Analisis Regresi Linier Berganda Coefficientsa

\begin{tabular}{|c|c|c|c|c|c|c|}
\hline \multicolumn{7}{|c|}{ Coefficients $^{\mathrm{a}}$} \\
\hline \multirow{2}{*}{\multicolumn{2}{|c|}{ Model }} & \multicolumn{2}{|c|}{$\begin{array}{l}\text { Unstandardized } \\
\text { Coefficients }\end{array}$} & \multirow{2}{*}{$\begin{array}{c}\text { Standardized } \\
\text { Coefficients } \\
\text { Beta }\end{array}$} & \multirow[t]{2}{*}{$\mathbf{T}$} & \multirow[t]{2}{*}{ Sig. } \\
\hline & & $\mathrm{B}$ & Std. Error & & & \\
\hline \multirow{4}{*}{1} & (Constant) & .299 & .416 & & .718 & .474 \\
\hline & Locus Of Control & .393 & .089 & .304 & 4.405 & .000 \\
\hline & $\begin{array}{l}\text { Kepemimpinan } \\
\text { Transformasional }\end{array}$ & .285 & .087 & .284 & 3.292 & .001 \\
\hline & Spiritual Kerja & .251 & .097 & .226 & 2.583 & .011 \\
\hline
\end{tabular}

a. Dependent Variable: Kinerja karyawan

Berdasarkan pada tabel 2 dapat disusun persamaan regresi sebagai berikut:

$\mathrm{Y}=299+0,393 \mathrm{X} 1+0,285 \mathrm{X} 2+0,251 \mathrm{X} 3$

Persamaan regresi di atas dapat diartikan sebagai berikut:

$\alpha=$ Nilai konstanta menunjukkan sebesar 0,299 menyatakan bahwa apabila locus of control, kepemimpiinan transformasional dan spiritual kerja bernilai nol maka kinerja karyawan sebesar 0,299. 
$\beta_{1}=$ Nilai koefisien regresi variabel locus of control menunjukkan nilai sebesar 0,393, menyatakan bahwa setiap peningkatan locus of control sebesar satu satuan maka menyebabkan kinerja karyawan meningkat sebesar 0,393 satuan dengan asumsi variabel lain tetap.

$\beta_{2}=$ Nilai koefisien regresi variabel kepemimpinan transformasional menunjukkan nilai sebesar 0,285, menyatakan bahwa setiap peningkatan kepemimpinan transformasional sebesar satu satuan maka menyebabkan knerja karyawan meningkat sebesar 0,285 satuan dengan asumsi variabel lain tetap.

$\beta_{3}=$ Nilai koefisien regresi variabel spiritual kerja menunjukkan nilai sebesar 0,251, menyatakan bahwa setiap peningkatan spiritual kerja sebesar satu satuan maka menyebabkan kinerja karyawan meningkat sebesar 0,251 satuan dengan asumsi variabel lain tetap.

Dari hasil analisis diatas pengaruh yang paling dominan terhadap kinerja karyawan adalah locus of control dengan nilai 0,393 , berikutnya variabel kepemimpinan transformasional dengan nilai 0,285 , berikutnya variabel Spritual kerja dengan nilai 0251.

Koefisien determinasi (R2) digunakan untuk mengukur seberapa jauh kemampuan model dalam menerangkan variasi variabel dependen. Berikut ini hasil uji koefisien determinasi pada penelitian ini dapat dilihat pada tabel 3 sebagai berikut:

Tabel. 3 Uji Determinasi R Square

\begin{tabular}{ccccc}
\multicolumn{5}{c}{ Model Summary } \\
\hline Model & $\mathrm{R}$ & R Square & Adjusted R Square & Std. Error of the Estimate \\
\hline 1 & $.629^{\mathrm{a}}$ & .396 & .383 & .22883 \\
\hline \multicolumn{4}{c}{ a. Predictors: (Constant), $\begin{array}{c}\text { Spritual Kerja, Locus Of Control, Kepemimpinan } \\
\text { Transformasional }\end{array}$}
\end{tabular}

Dari data diatas dapat dilihat Adjusted R-Square dari model regresi yang terbentuk dalam penelitian ini adalah sebesar 0,383. Hal ini berarti 38,3\% variabel kinerja karyawan dapat dijelaskan oleh ke tiga variabel independen (locus of control, kepemimpinan transformasional dan spiritual kerja) sedangkan sisanya sebesar $61,7 \%$ dipengaruhi oleh variabel lain yang tidak masuk dalam model penelitian. 


\section{Uji Simultan F}

\section{Pengaruh, Locus of Control, Kepemimpinan Transformasional dan Spritual Kerja Berpengaruh Secara Simultan Terhadap Kinerja Karyawan}

Uji statistik f digunakan untuk mengetahui apakah variabel independen secara bersama-sama atau simultan mempengaruhi variabel dependen. Pengujian secara simultan ini dilakukan dengan cara membandingkan tingkat signifikansi f dari hasil pengujian dengan nilai signifikansi yang digunakan dalam penelitian (Ghozali, 2016). Hasil uji f dalam penelitian ini tersaji sebagai berikut:

\section{Tabel 4. Uji F}

Hasil Uji F

\begin{tabular}{lllllll}
\multicolumn{7}{c}{ ANOVA $^{\mathrm{a}}$} \\
\hline \multicolumn{2}{l}{ Model } & Sum of Squares & Df & Mean Square & F & Sig. \\
\hline \multirow{3}{*}{1} & Regression & 4.833 & 3 & 1.611 & 30.768 & $.000^{\mathrm{b}}$ \\
& Residual & 7.383 & 141 & .052 & & \\
& Total & 12.216 & 144 & & & \\
\hline
\end{tabular}

a. Dependent Variable: Kinerja

Karyawan

b. Predictors: (Constant), Spritual Kerja, Locus Of Control, Kepemimpinan Transformasional

Berdasarkan dari tabel diatas dapat diketahui nilai $\mathrm{F}_{\text {hitung }}$ adalah 30,768 dengan nilai signifikansi 0,000. Sedangkan $F$ tabel pada tingkat signifikan 0,05 adalah sebesar 2,67, (df 1=(K-1) 4-1=3 dan df 2=(N-K-1) 145-3-1=141). Nilai $\mathrm{F}_{\text {hitung }}>\mathrm{F}_{\text {tabel }}$ $(30,768>2,67)$.

Nilai signifikansi sebesar $0,000<0,05$, sehingga dapat disimpulkan terdapat pengaruh secara simultan antara locus of control, kepemimpinan transformasional dan spiritual kerja terhadap kinerja karyawan. Sehingga hipotesis pertama yang menyatakan locus of control, kepemimpinan transformasional dan spiritual kerja berpengaruh secara simultan dapat diterima. 


\section{Uji Parsial ( $t$ test)}

\section{Locus Of Control Berpengaruh Signifikan Terhadap Kinerja Karyawan.}

Berdasarkan hasil pengujian di peroleh nilai t hitung $>$ nilai $t$ tabel $(4,405>1,98498)$ dan nilai signifikansi $<$ dari $0,05(0,000<0,05)$, maka dapat disimpulkan bawa variabel locus of control berpengaruh signifikan terhadap kinerja karyawan, sehingga hipotesis kedua yang menyatakan locus of control berpengaruh signifikan terhadap kinerja karyawan.

Karyawan Perum Perhutani KPH Banyumas Timur selama ini berupaya melakukan pekerjaan sebaik mungkin untuk kemajuan organisasi, sehingga dapat meningkatkan kinerja karyawan, dan dapat disimpulkan locus of control berperan dalam menentukan kinerja karyawan, sehingga dapat disimpulkan locus of control berperan dalam menentukan kinerja karyawan.

Hasil penelitian ini sejalan dengan teori yang menyatakan Locus of control merupakan salah satu faktor yang memengaruhi kinerja karyawan karena ketika mereka berkinerja dengan baik, mereka yakin bahwa hal tersebut disebabkan oleh usaha atau keterampilan mereka. Locus of control secara teoritis berpengaruh terhadap kinerja karyawan, hal ini dikarenakan locus of control mencakup beberapa aspek yaitu percaya pada kemampuan diri, percaya pada usaha, keyakinan pada kekuatan orang lain dan percaya pada nasib yang bersumber dari karyawan tersebut.

Hasil Penelitian ini sejalan dengan penelitian terdahulu yang dilakukan oleh Narendra (2018) menghasilkan locus of control berpengaruh signifikan terhadap kinerja karyawan, namun berbeda dengan penelitian yang dilakukan oleh Srimindanti dan Haryanto, (2020) yang mengatakan bahwa locus of control tidak berpengaruh signifikan terhadap kinerja karyawan.

\section{Kepemimpinan Transformasional Berpengaruh Signifikan Terhadap Kinerja Karyawan.}

Berdasarkan hasil pengujian tersebut di peroleh nilai t hitung $>$ nilai t tabel $(3,292>1,98498)$ dan nilai signifikansi < dari 0,05 $(0,001<0,05)$, maka dapat disimpulkan bawa variabel kepemimpinan transformasional berpengaruh signifikan terhadap kinerja karyawan. Hipotesis ketiga yang menyatakan kepemimpinan transformasional berpengaruh signifikan terhadap kinerja karyawan dapat diterima. 
Kepemimpinan transformasional di Perhutani KPH Banyumas Timur dapat diterapkan dengan baik, sehingga dapat meningkatkan semangat karyawan, memotivasi karyawan, mampu membuat fikiran karyawan terbuka dan mampu menginspirasi bagi setiap karyawannya, maka dapat disimpulkan kepemimpinan transformasional berperan dalam menentukan kinerja karyawan, sehingga kepemimpinan transformasional berperan dalam menentukan kinerja karyawan.

Hasil penelitian ini sejalan dengan teori Kepemimpinan transformasional yang menyatakan bahwa kepemimpinan transformasional merupakan pemimpin yang mampu memberikan pengaruh positif dan motivasi yang baik terhadap karyawannya dapat meningkatkan kualitas kinerja pegawai, sebaliknya pimpinan yang tidak mampu memberikan pengaruh positif dan hanya dapat memberikan tekanan pada karyawannya Maka dapat mempengaruhi menurunnya kinerja pegawai. Sehingga kepemimpinan transformasional memiliki pengaruh yang cukup besar terhadap kinerja karyawan (Jufrizen, 2020).

Hasil penelitian ini didukung oleh beberapa penelitian terdahulu, diantaranya Galan (2018), Yuniawan (2016) memperoleh hasil penelitian bahwa kepemimpinan transformasional berpengaruh signifikan terhadap kinerja karyawan, Berdasarkan definisi dan acuan penelitian terdahulu dapat disimpulkan bahwa kepemimpinan transformasional berpengaruh signifikan terhadap kinerja karyawan. Namun berbeda dengan penelitian yang dilakukan oleh Gita (2016) yang menyatakan bahwa kepemimpinan transformasional tidak berpengaruh terhadap kinerja karyawan.

\section{Spritual Kerja Berpengaruh Signifikan Terhadap Kinerja Karyawan.}

Berdasarkan hasil pengujian tersebut di peroleh nilai t hitung > nilai t tabel $(2,583>1,98498)$ dan nilai signifikansi < dari 0,05 $(0,011<$ 0,05 ), maka dapat disimpulkan bawa variabel spiritual kerja berpengaruh signifikan terhadap kinerja karyawan. Sehingga hipotesis keempat yang menyatakan spiritual kerja berpengaruh signifikan terhadap kinerja karyawan, diterima.

Spiritual yang baik dalam dirinya dapat memberikan semangat dan motivasi untuk melakukan pekerjaan dengan sepenuh hati dan berusaha untuk dapat meningkatkan organisasi, maka dapat disimpulkan spiritual 
kerja berperan dalam menentukan kinerja karyawan, sehingga spiritual kerja berperan dalam menentukan kinerja karyawan.

Hasil penelitian ini sejalan dengan teori yang menyatakan bahwa spiritualitas di tempat kerja mendorong karyawan untuk lebih berkomitmen terhadap organisasi, sehingga mampu menurunkan tingkat absensi dan keluar masuknya karyawan. Spiritualitas digunakan sebagai motif bekerja secara individual, dan secara interaktif spiritualitas personal dan organisasi mampu mempengaruhi penghargaan karyawan terhadap pekerjaannya. Organisasi spiritual cenderung lebih partisipatif dan inklusif dalam membuat keputusan dan berbagi informasi, sehingga membantu karyawan merasa berdaya dan penting (Hanah, 2019).

Hasil penelitian ini sejalan dengan penelitian yang dilakukan oleh Nasrul (2018), menghasilkan Spiritual at work berpengaruh signifikan terhadap kinerja karyawan. Namun berbeda dengan penelitian Octavia, (2020) menyatakan bahwa spritualitas kerja tidak erpengaruh signifikan terhadap kinerja karyawan.

\section{SIMPULAN}

Berdasarkan analisis yang telah dilakukan, maka dapat ditarik beberapa simpulan Locus of control, Kepemimpinan transformasional dan spiritual kerja berpengaruh secara simultan terhadap kinerja karyawan Perum Perhutani KPH Banyumas Timur sehingga hipotesis pertama diterima, Locus of control secara parsial berpengaruh signifikan terhadap Perum Perhutani KPH Banyumas Timur sehingga hipotesis kedua diterima, Kepemimpinan transformasional secara parsial signifikan terhadap Perum Perhutani KPH Banyumas Timur hipotesis ketiga diterima, dan Spritual Kerja secara parsial berpengaruh signifikan terhadap Perum Perhutani KPH Banyumas Timur sehingga hipotesis diterima.

Pada penelitian ini adjusted $R$ square masih rendah sebesar 0,383 (38,3\%) sebaiknya penelitian selanjutnya menggunakan, mengganti atau menambahkan variabel-variabel lain yang potensial memberikan kontribusi meningkatkan kinerja karyawan, seperti kompensasi dan lingkungan kerja. 


\section{DAFTAR PUSTAKA}

Allen, Graham. (2003). Roland Barthes. London: Routledge

Annida, (2018). Independen : Locus Of Control, Dependen : Kinerja Karyawan, Jurnal Wawasan Manajemen, Vol. 6 Nomor 3, 2018 ISSN: 1693-5241

Bagis, F., \& Pratama, B. (2020). The Effect of Leadership, Reward And Punishment on Employee Performance (Case Study Sambel Layah Corporation Purwokerto). https://doi.org/10.4108/eai.5-8-2020.2301082

Bagis, F., Kusumo, U. I., \& Hidayah, A. (2021). Job Satisfaction as a Mediation Variables on The Effect Organization Culture and Organizational Commitment to Employee Performance. International Journal of Economics, Business and Accounting Research (IJEBAR), 5(2), 424-434. https://doi.org/10.18551/ rjoas.2021-03.09

Davis, Keith. 1985. Perilaku Dalam Organisasi. Jakarta: Erlangga.

Fauzi. 2020. Locus of control Dependent : Kinerja karyawan, Jurnal Sains Sosio Humaniora P-ISSN: 2580-1244 Volume 4 Nomor 2. E-ISSN: 2580-2305.

Galan, (2018). Pengaruh gaya kepemimpinan transformasional, budaya organisasi dan motivasi kerja terhadap kinerja karyawan (studi pada karyawan PD BPR BKK taman pemalang), Dipenegoro journal of management ,Volume 7, Nomor 2, tahun 2018, halaman 1-11 ISSN (online) 2337-3792.

Gibson, L James., Ivancevich, M John \& Donnelly, H James jr. 1995. Organisasi, Edisi ke delapan, Jilid 1. Jakarta: Binarupa Aksara.

Gita, Robertus dan Ahyar. 2016. Pengaruh Gaya Kepemimpinan Transformasional, Motivasi Kerja dan Budaya Organiasi terhadap Kinerja karyawan. Diponegoro Journal of Management Vol 05. No 03, hal. 1 - 12.

Haryanto dkk, (2020). Analisis pengaruh locus of control dan emotional intelligence terhadap kinerja karyawan dengan stress kerja sebagai variabel intervening (studi pada PT Telkom divre jateng dan DIY, Advance : Jurnal Akuntansi ISSN : 2337-5221 (cetak), Vol 7, No 1 (July, 2020)

Hanah (2019), Pengaruh spiritual intelligence dan organizational culture terhadap kinerja karyawan melalui organizational, Scientific journal of reflection: p-ISSN 2615-3009, Economic, Accounting, Management and Business e-ISSN 2621-3389, Vol. 2, No. 3, July 2019 
Jex, M.S., \& Britt, W.T. 2008. Organizational Psychology: a scientistpractitioner approach-2nd ed. New Jersey: John Wiley \& Sons, inc

Jufrizen J, Afni Sasqia Putri Lubis. P.S.A (2020). Pengaruh Kepemimpinan Transformasional dan Kepemimpinan Transaksional terhadap Kinerja Pegawai Dengan Locus Of Control Sebagai Variabel Moderating. Jurnal Ilmiah Magister Manajemen, Vo. 3.No 1, ISSN; 2632 2634. http://jurnal.umsu.ac.id/ index.php/MANEGGIO/article/view/4874

Kharis, Indra,(2015). Pengaruh Gaya Kepemimpinan Transformasional Terhadap Kinerja Karyawan Dengan Motivasi Kerja Sebagai Variabel Intervening (Studi Pada Karyawan Bank Jatim Cabang Malang),Jornal Administrasi Bisnis. http:// administrasibisnis.studentjournal.ub.ac.id/index.php/jab/article/view/816

Levenson, Hanna, (1981), Differentiating Among Internalit, Powerful Others, and Chance, Journal Research With The Locus of Control Construct Vol. 1, Academic Press

Mathis Robert, Jackson John. 2002. Manajemen Sumber Daya Manusia. Jakarta : Salemba empat

Mukaffi, (2020), pengaruh gaya kepemimpinan transformasional iklim organisasi dan disiplin kerja terhadap kinerja karyawan perguruan tinggi swasta di kota bima, Jurnal GeoEkonomi ISSN-Elektronik (e): 2503-4790 | ISSN-Print (p): 2086-1117, Volume 11 Nomor 1, Maret 2020.

Narendra, (2018). Pengaruh locus of control dan kemampuan mengoperasikan teknologi terhadap kinrja karyawan pada PT penggadaian (persero) Denpasar tahun 2015, Journal Of Economics and Management, E-ISSN. 2614-4212 (Online), ISSN 1411-5794 (Cetak), Volume 19, No. 2 - Juni 2018.

Nasrul. 2018. Kecerdasan intelektual, kecerdasan emosional, kecerdasan spiritual dan kecerdasan linguistic terhadap kinerja karyawan, Journal of Applied Business Administration, ISSN 2548-9909.

Octavia (2020), Analisis pengaruh kompentensi syariah, kompetensi islam dan kecerdasan spiritual terhadap kinerja karyawan (studi kasus bank muamalat cabang ternate), Jurnal Bisnis dan Manajemen, Volume 16 No. 2, Mei 2020, 130-144, ISSN 1411 - 9366130.

Puspitayanti, Dwi Eny Ni Kadek. 2015. Pengaruh Locus Of Control Dan Kemampuan Mengoperasikan Teknologi Informasi Terhadap Kinerja Karyawan Pada 
Pt Pegadaian (Persero) Denpasar. Vol: 5 Nomor: 1, Singaraja: Universitas Pendidikan Ganesha

Robbins SP, dan Judge. 2007. Perilaku Organisasi, Salemba Empat, Jakarta

Robinson, J. P., Shaver, P. R., \& Wrightsman, L. S., (1991), Measure of Personality and Social Psychological Attitudes, Clifornia, Academic Press, Inc

Sari, (2018). Pengaruh karakteristik budaya organisasi locus of control dan disiplin kerja karyawan studi pada perusahaan daerah pengelola air limbah (PD PAL) kota banjamasin, Jurnal Ekobistek Fakultas Ekonomi , Vol. 7, No. 1, April 2018, Hal 9-18, ISSN : 2301-5268 | E-ISSN : 2527-9483.

Sudarman. 2017. Pengaruh spiritualitas tempat kerja, kepemimpinan spiritual, kelebihan beban kerja pada kinerja karyawan, Management Analysis Journal 6 (2). ISSN 2252-6552

Sudaryono. 2014. Budaya dan Perilaku Organisasi. Jakarta : Lentera Ilmu Cendekia

Timpe, A. Dale. 1988. The Art and Science of Business Management Productivity. New York: Kend Publishing.

Yuniawan, (2016). Pengaruh gaya kepemimpinan transformasional terhadap kinerja karyawan dengan motivasi kerja sebagai variable intervening (studi pada karyawan bank jatim cabang malang), Dipenegoro journal of management, Volume 5, Nomor 3, Tahun 2016, Halaman 1-12, ISSN (Online): 2337-3814.

Yuwono, (2020). Peran komitmen organisasi sebagai mediasi hubungan kepemimpinan transformasional dan sistem reward terhadap kinerja karyawan Jurnal Ilmiah Mahasiswa Ekonomi Manajemen, Vol. 5, No. 3, 615632 E-ISSN: 2598-635X, P-ISSN: 2614-7696

Zohar, Danah dan Marshall, Ian. 2000. SQ: Kecerdasan Spiritual. Terjemahan (SQ) Spiritual Intelligence - The Ultimate Intelligence. Bandung: Mizan Pustaka. 
halaman ini sengaja untuk dikosongkan 